\title{
Pengoptimuman Sensor Resonans Plasmon Permukaan berdasarkan Kretschmann dengan Kaedah Taguchi
}

(Optimization of Kretschmann based on Surface Plasmon Resonance Sensor using Taguchi Method)

\author{
GAN SIEW MEI, NAJMIAH RADIAH BINTI MOHAMAD, NUR AKMAR BINTI JAMIL, \\ BURHANUDDIN YEOP MAJLIS \& P. SUSTHITHA MENON*
}

\begin{abstract}
In this paper, Taguchi experimental design technique was applied for optimization of chromium $(\mathrm{Cr}) /$ silver $(\mathrm{Ag}) / \mathrm{indium}$ tin oxide (ITO) SPR sensor for operation in near infrared region. Four factors were considered which include wavelength, thickness of Cr, thickness of Ag, and thickness of ITO. Finite-difference-time-domain (FDTD) method was used in numerical analysis for minimum reflectance $\left(R_{\text {min }}\right)$ and full-width-at-half-maximum (FWHM) performance parameters. The results obtained from the Taguchi method shows that the optimized parameter for $R_{\text {min }}$ was $785 \mathrm{~nm}$ of wavelength, Cr $(1 \mathrm{~nm})$, $\mathrm{Ag}(40 \mathrm{~nm})$ and ITO $(20 \mathrm{~nm})$, whereas the optimized parameter for FWHM was 785 of wavelength, $C r(0 \mathrm{~nm}), \mathrm{Ag}(40 \mathrm{~nm})$ and ITO $(0 \mathrm{~nm})$. In short, the optimum parameters for achieving the desired performance of sensor were successfully predicted using Taguchi optimization method.
\end{abstract}

Keywords: Indium tin oxide; Kretschmann configuration; silver; surface plasmon resonance; Taguchi method

\section{ABSTRAK}

Dalam makalah ini, teknik reka bentuk uji kaji Taguchi telah digunakan untuk mengoptimumkan sensor SPR kromium $(\mathrm{Cr}) /$ perak $(\mathrm{Ag}) /$ indium timah oksida (ITO) untuk operasi berhampiran gelombang inframerah. Empat faktor yang dipilih termasuk panjang gelombang, ketebalan Cr, ketebalan Ag dan ketebalan ITO. Kaedah perbezaan-terhingga-domain-masa (FDTD) digunakan untuk analisis berangka prestasi parameter pantulan minimum $\left(R_{\text {min }}\right)$ dan penuh-lebar-pada-separuhmaksimum (FWHM). Keputusan kajian yang diperoleh daripada kaedah Taguchi menunjukkan bahawa parameter yang dioptimumkan untuk $R_{\min }$ adalah panjang gelombang (785 nm), Cr (1 nm), Ag (40 nm) dan ITO (20 nm). Manakala parameter yang dioptimumkan untuk FWHM adalah panjang gelombang (785 nm), Cr (0 nm), Ag (40 nm) dan ITO (0 nm). Dengan ini parameter optimum untuk mencapai prestasi sensor yang diingini berjaya diramal menggunakan kaedah pengoptimuman Taguchi.

Kata kunci: Indium timah oksida; kaedah Taguchi; perak; resonans plasmon permukaan; tatarajah Kretschmann

\section{PENGENALAN}

Teknik penderiaan tanpa label menggunakan prinsip resonans plasmon permukaan (SPR) semakin popular dalam bidang sains analitik. Ia menawarkan sistem ujian lebih mudah berbanding teknik konvensional yang memerlukan pelabelan enzim, pendarfluor warna, zarah dan lain-lain (Manesse et al. 2008). Salah satu geometri sering digunakan dalam sensor SPR adalah konfigurasi Kretschmannn. Dalam konfigurasi ini, sinar polarisasi-p yang melalui prisma ke atas permukaan logam akan menjana gelombang plasmon permukaan (SPW). Apabila pemalar perambatan sinar di sepanjang antaramuka sepadan dengan pemalar perambatan SPW, ayunan kolektif elektron permukaan logam berlaku. Dalam keadaan ini, tenaga daripada pancaran cahaya berpindah ke plasmon permukaan lalu membentuk fenomena SPR. Ini menyebabkan penurunan ketara pada isyarat pantulan dan membentuk kemiringan tajam pada spektrum pantulan. Anjakan miring pantulan yang disebabkan oleh perubahan indeks bias analit boleh digunakan dalam applikasi penderiaan. Sebagai contoh, dalam mod pemesotan sudut, perubahan indeks bias analit akan menyebabkan anjakan sudut resonans (Mukhtar et al. 2013).

Secara umumnya, kebanyakan sensor SPR dikaji dalam gelombang cahaya nampak kerana bahan logam yang aktif dalam gelombang ini adalah mudah didapati seperti emas (Ag) dan perak (Ag) (Nengsih et al. 2011; Said et al. 2015). Sejak kebelakangan ini, sensor SPR yang beroperasi berhampiran gelombang inframerah (NIR) mendapat perhatian khusus dalam bidang perubatan (Huang 2017). Antara kelebihan sensor SPR yang beroperasi dalam NIR adalah gelombang evanescent dalam NIR dapat menembus jauh ke dalam analit dan memberikan sensitiviti yang tinggi. Selain itu, kerosakan sel-sel hidup akibat frekuensi gelombang tinggi juga dapat dielakkan dengan menggunakan sensor dalam NIR. Untuk membina sensor SPR yang beroperasi dalam NIR, Indium timah oksida (ITO) telah digunakan sebagai salutan plasmonik. ITO juga dapat melindungi Ag daripada pengoksidaan. Ag pula terkenal dengan spektrum resonans yang tajam. Namun begitu, 
Ag amat jarang digunakan untuk fungsi penderiaan SPR. Sebab utamanya adalah ia mudah teroksida apabila digunakan dalam persekitaran cecair dan udara kerana kestabilan kimianya lemah (Wang et al. 2017). Keadaan ini menjadikan sensitiviti sensor berkurang. Oleh itu, lapisan Ag perlu disaluti dengan lapisan perlindung seperti ITO supaya dapat mencapai tahap kestabilan yang diingini dan seterusnya membentuk sensor SPR yang beroperasi dalam NIR.

Dalam kajian ini, parameter optimum untuk prestasi sensor SPR yang diingini dikaji menggunakan kaedah Taguchi. Kaedah ini menggunakan tatacara ortogon (OA) untuk mengkaji kesan utama hanya dengan menggunakan bilangan eksperimen yang minimum, sekaligus menjimatkan masa dan sumber (Chen et al. 2017). Hal ini demikian kerana susunan ortogonal Taguchi merupakan reka bentuk faktoran dan kaedah ini berdasarkan statistik, bukannya pemodelan (Simha 2012). Pada awalnya, kaedah Taguchi dibangunkan untuk meningkatkan kualiti barangan dalam bidang pembuatan. Dalam melangkah ke era modenisasi, kaedah ini telah banyak diterapkan dalam bidang kejuruteraan (Menon et al. 2014; Oktiawati et al. 2017; Salehuddin et al. 2014; Sinnathambi \& Ismail 2012).

Justeru, dalam makalah ini, kaedah Taguchi telah diadaptasikan untuk pengoptimunan prestasi sensor SPR Cr/Ag/ITO dengan mengambil kira beberapa faktor kritikal iaitu panjang gelombang cahaya, ketebalan $\mathrm{Cr}$, ketebalan Ag dan ketebalan ITO. Objektif penyelidikan ini dijalankan adalah untuk mereka sensor SPR yang beroperasi dalam gelombang NIR menggunakan bahan yang terdiri daripada Cr, Ag dan ITO. Kajian ini direka menggunakan kaedah Taguchi dengan mengkaji setiap kesan faktor individu, gabungan faktor optimum telah ditentukan.

\section{KAEDAH KAJIAN}

\section{ANALISIS BERANGKA}

Dalam kajian ini, perisian Lumerical FDTD Solutions digunakan untuk memperoleh respons SPR daripada penyelesaian persamaan Maxwell. Perisian FDTD ini berkebolehan untuk melakukan sapuan parameter dengan pemisitan sudut dalam julat sudut sumber cahaya akan menentukan sudut resonans. Sensor tersebut direka pada atas substrak BK7 dan terdiri daripada tiga lapisan, iaitu $\mathrm{Cr}, \mathrm{Ag}$ dan ITO. Rajah 1 menunjukkan sensor SPR Cr/ Ag/ITO yang dicadangkan dengan Ag digunakan sebagai lapisan aktif SPR, Cr sebagai pelekat antara lapisan Ag dan subtrak BK7 serta ITO sebagai lapisan pelindung. Lapisan padanan sempurna (PML) digunakan sebagai syarat sempadan untuk mengira pemalar perambatan gelombang yang mengurangkan pantulan di sempadan serakan gelombang. Monitor masa, monitor penghantaran dan monitor pemantulan ditetapkan. Simulasi dengan komputer peribadi berjalan selama kira-kira dua jam untuk setiap parameter. Parameter optimum yang dikenal pasti digunakan untuk mereka bentuk eksperimen Taguchi.

\section{REKA BENTUK UJI KAJI DENGAN KAEDAH TAGUCHI}

Faktor kritikal yang berpengaruh tinggi terhadap sensitiviti sensor SPR Cr/Ag/ITO seperti panjang gelombang, ketebalan $\mathrm{Cr}$, ketebalan Ag, dan ketebalan ITO telah ditentukan untuk kaedah Taguchi. Seterusnya, matriks direka dengan OA yang sesuai untuk bilangan faktor terpilih dan tahap bagi setiap faktor tersebut. Dalam kajian ini, OA L9 (yang menunjukan sembilan eksperimen percubaan) dipilih untuk faktor terkawal di atas dengan tiga tahap variasi faktor (Jadual 1).

Prestasi sensor boleh dijelaskan dengan nilai $\mathrm{R}_{\min }$ dan FWHM. Nilai $R_{\text {min }}$ dan FWHM yang kecil memberikan ketepatan sensor yang terbaik. Nilai FWHM boleh ditentukan dengan mengira lebar penuh pada separuh maksimum pada miring pemantulan $\left(\Delta \theta_{0.5}\right)$ yang dinyatakan sebagai:

$$
\mathrm{FWHM}=\Delta \theta_{0.5}
$$

dengan kaedah Taguchi, nilai-nilai $\mathrm{R}_{\text {min }}$ dan FWHM yang diperoleh daripada analisis berangka FDTD telah ditukar dan dilaporkan dalam bentuk nisbah isyarat hinggar $(\mathrm{S} / \mathrm{N})$ menggunakan perisian Minitab. Nisbah S/N yang

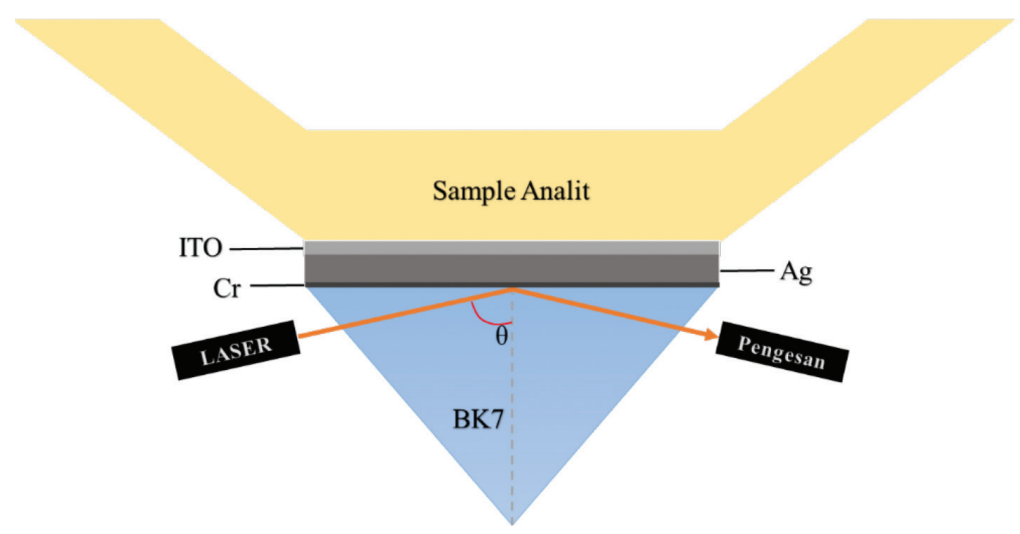

RAJAH 1. Konfigurasi Kretschmann sensor SPR Cr/Ag/ITO 
merupakan fungsi logaritma membantu untuk menganalisis data serta meramal hasil optimum. Terdapat tiga kategori ciri prestasi nisbah $\mathrm{S} / \mathrm{N}$ iaitu nominal terbaik, terbesar terbaik dan terkecil terbaik. Kajian ini adalah untuk mendapatkan prestasi optimum sensor SPR, iaitu nilai $\mathrm{R}_{\text {min }}$ dan FWHM yang kecil, maka nisbah $\mathrm{S} / \mathrm{N}$ yang terkecil terbaik dipilih dan dikira menggunakan (2):

$$
\frac{\mathrm{S}}{\mathrm{N}}=-10 \log \frac{1}{\mathrm{n}}\left(\sum y^{2}\right)
$$

Seterusnya, kesan utama ditentukan melalui analisis varians (ANOVA). Untuk mengesahkan keputusan kaedah Taguchi pula, simulasi dijalankan mengunakan gabungan faktor sensor SPR yang telah dioptimumkan.

JADUAL 1. Reka bentuk uji kaji

\begin{tabular}{clccc}
\hline No. & \multicolumn{1}{c}{ Faktor } & Tahap & Tahap & Tahap \\
Siri & & 1 & 2 & 3 \\
\hline 1 & Panjang gelombang $(\mathrm{nm})$ & 632.8 & 670 & 785 \\
2 & Ketebalan Cr $(\mathrm{nm})$ & 0 & 0.5 & 1 \\
3 & Ketebalan Ag $(\mathrm{nm})$ & 20 & 30 & 40 \\
4 & Ketebalan ITO $(\mathrm{nm})$ & 0 & 10 & 20 \\
\hline
\end{tabular}

\section{KEPUTUSAN DAN PERBINCANGAN}

\section{ANALISIS BERANGKA}

Pada mulanya, pengoptimuman parameter sensor SPR $\mathrm{Cr} / \mathrm{Ag} / \mathrm{ITO}$ daripada simulasi awal menunjukkan panjang gelombang $(678 \mathrm{~nm})$, ketebalan $\mathrm{Cr}(0.5 \mathrm{~nm})$, ketebalan Ag (30 nm), dan ketebalan ITO (10 nm) merupakan faktor kritikal untuk prestasi sensor yang maksimum seperti yang ditunjukkan dalam Rajah 2. Dengan parameter ini, sensor tersebut menunjukkan nilai $\mathrm{R}_{\min }$ dan FWHM masing-masing 0.09034 dan $1.64^{\circ}$. Hasil kajian ini mencadangkan bahawa pengoptimuman setiap parameter rekaan sensor seperti panjang gelombang sinar dan ketebalan lapisan $\mathrm{Cr}, \mathrm{Ag}$ dan ITO adalah pra-syarat fabrikasi sensor untuk digunakan dalam applikasi biosensor. Walau bagaimanapun, kaedah pengoptimuman konvensional tidak memberikan maklumat mengenai pengaruh interaktif faktor-faktor yang menyumbang kepada prestasi sensor yang tinggi. Oleh itu, pengoptimuman parameter sensor $\mathrm{Cr} / \mathrm{Ag} / \mathrm{ITO}$ telah dilakukan secara Taguchi dengan menggunakan empat faktor kritikal rekaan sensor dan tahap terpililh bagi setiap faktor itu (Jadual 1). Kesemua faktor dan tahap dipilih adalah berdasarkan analisis berangka awal yang dijalankan.

\section{REKA BENTUK UJI KAJI TAGUCHI}

Kesan panjang gelombang sinar, ketebalan lapisan $\mathrm{Cr}, \mathrm{Ag}$ dan ITO telah dikaji dengan menggunakan kaedah Taguchi yang merupakan reka bentuk uji kaji L9 $\left(3^{4}\right)$ OA (Jadual 2). Nilai $R_{\text {min }}$ dan FWHM yang ditunjukkan dalam Jadual 2 diperoleh daripada simulasi manakala nilai nisbah $\mathrm{S} / \mathrm{N}$ dikira berdasarkan (2). Nisbah S/N yang ditunjukkan berdasarkan kepada terkecil terbaik dan nilai optimumnya diwakili oleh nisbah $\mathrm{S} / \mathrm{N}$ yang terbesar.

Prestasi sensor didapati sangat bergantung kepada parameter reka bentuk sensor. Jadual 3 dan 4 menunjukkan respons nisbah $\mathrm{S} / \mathrm{N}\left(\mathrm{R}_{\min }\right)$ dan (FWHM). Nisbah $\mathrm{S} / \mathrm{N}$ tertinggi untuk $\mathrm{R}_{\text {min }} 18.781$, 20.619, 22.643 dan 19.198 telah diperolehi dengan panjang gelombang, ketebalan $\mathrm{Cr}$, Ag dan ITO masing-masing di tahap 3. Penurunan ke tahap 1 dan 2 menyebabkan penurunan nisbah $\mathrm{S} / \mathrm{N}$ $\mathrm{R}_{\text {min }}$. Seterusnya, panjang gelombang dan ketebalan Ag menyebabkan nisbah S/N (FWHM) tinggi di tahap 3, iaitu masing-masing -9.111 dan -3.419. Ketebalan $\mathrm{Cr}$ dan ITO pula memberikan kesan tinggi di tahap 1, iaitu masingmasing sebanyak -9.198 dan -8.142. Penambahan lapisan $\mathrm{Cr}$ dan ITO telah menyebabkan penurunan nisbah $\mathrm{S} / \mathrm{N}$ (FWHM). Perbezaan antara nilai nisbah $\mathrm{S} / \mathrm{N}$ terbesar dan terkecil di setiap faktor menunjukkan pengaruh relatif oleh setiap faktor. Semakin besar perbezaan itu, semakin besar pengaruhnya. Dapat dilihat dalam Jadual 3 dan 4 bahawa antara faktor-faktor yang dikaji, ketebalan Ag memberikan pengaruh besar berbanding faktor-faktor lain.

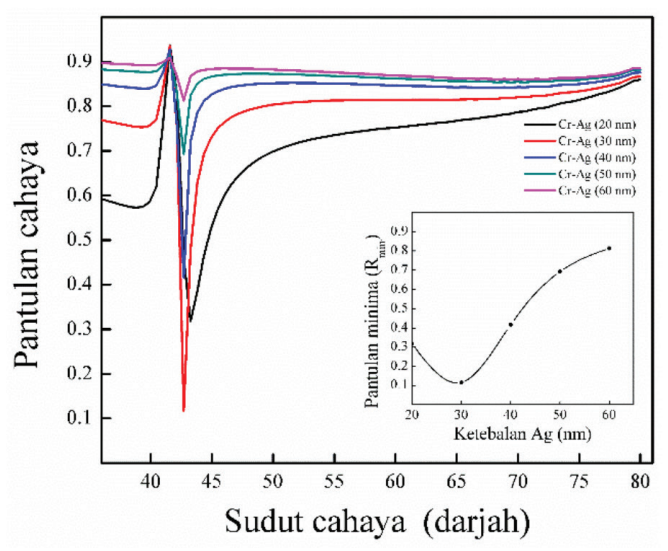

(a)

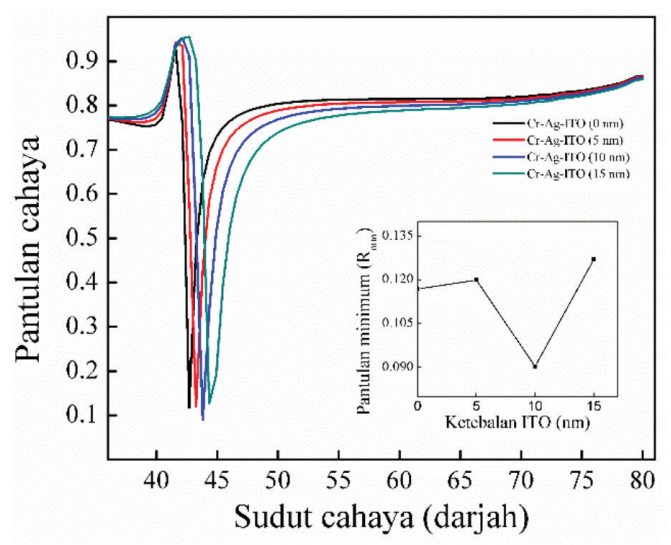

(b)

RAJAH 2. Ketebalan a) Ag b) ITO yang optima dalam simulasi awal 
JADUAL 2. Keputusan ujian simulasi dan nisbah S/N yang dihitung

\begin{tabular}{|c|c|c|c|c|c|c|c|c|}
\hline \multirow{2}{*}{ No. Eksperimen } & \multicolumn{4}{|c|}{ L9 } & \multirow{2}{*}{$\mathrm{R}_{\min }$} & \multirow{2}{*}{$\begin{array}{c}\text { FWHM } \\
\text { (darjah) }\end{array}$} & \multirow{2}{*}{$\mathrm{S} / \mathrm{N} \mathrm{R}_{\min }$} & \multirow{2}{*}{ S/N FWHM } \\
\hline & 1 & 2 & 3 & 4 & & & & \\
\hline 1 & 1 & 1 & 1 & 1 & 0.5566 & 10.8219 & 5.11 & -20.66 \\
\hline 2 & 1 & 2 & 2 & 2 & 0.2097 & 5.3796 & 13.61 & -14.58 \\
\hline 3 & 1 & 3 & 3 & 3 & 0.02801 & 3.8874 & 31.08 & -11.76 \\
\hline 4 & 2 & 1 & 2 & 3 & 0.1235 & 2.4202 & 18.18 & -7.66 \\
\hline 5 & 2 & 2 & 3 & 1 & 0.4170 & 0.9154 & 7.64 & 0.79 \\
\hline 6 & 2 & 3 & 1 & 2 & 0.2465 & 10.6088 & 12.20 & -20.46 \\
\hline 7 & 3 & 1 & 3 & 2 & 0.0343 & 0.9154 & 29.34 & 0.78 \\
\hline 8 & 3 & 2 & 1 & 3 & 0.3804 & 15.1231 & 8.42 & -23.56 \\
\hline 9 & 3 & 3 & 2 & 1 & 0.1168 & 1.6803 & 18.68 & -4.48 \\
\hline
\end{tabular}

JADUAL 3. Jadual respons nisbah $\mathrm{S} / \mathrm{N}$ untuk nilai $\mathrm{R}_{\min }$

\begin{tabular}{ccccc}
\hline Tahap & $\begin{array}{c}\text { Panjang gelombang } \\
(\mathrm{nm})\end{array}$ & $\begin{array}{c}\text { Ketebalan Cr } \\
(\mathrm{nm})\end{array}$ & $\begin{array}{c}\text { Ketebalan Ag } \\
(\mathrm{nm})\end{array}$ & $\begin{array}{c}\text { Ketebalan ITO } \\
(\mathrm{nm})\end{array}$ \\
\hline 1 & 16.565 & 17.515 & 8.551 & 10.448 \\
2 & 12.641 & 9.854 & 16.794 & 18.342 \\
3 & 18.781 & 20.619 & 22.643 & 19.198 \\
Delta & 6.140 & 10.765 & 14.092 & 8.750 \\
Peringkat & 4 & 2 & 1 & 3 \\
\hline
\end{tabular}

JADUAL 4. Jadual respons nisbah S/N untuk nilai FWHM

\begin{tabular}{ccccc}
\hline Tahap & $\begin{array}{c}\text { Panjang gelombang } \\
(\mathrm{nm})\end{array}$ & $\begin{array}{c}\text { Ketebalan Cr } \\
(\mathrm{nm})\end{array}$ & $\begin{array}{c}\text { Ketebalan Ag } \\
(\mathrm{nm})\end{array}$ & $\begin{array}{c}\text { Ketebalan ITO } \\
(\mathrm{nm})\end{array}$ \\
\hline 1 & -15.698 & -9.198 & -21.597 & -8.142 \\
2 & -9.141 & -12.480 & -8.933 & -11.454 \\
3 & -9.111 & -12.271 & -3.419 & -14.354 \\
Delta & 6.587 & 3.282 & 18.178 & 6.212 \\
Peringkat & 2 & 4 & 1 & 3 \\
\hline
\end{tabular}

Rajah 3 dan 4 menunjukkan plot kesan utama nisbah $\mathrm{S} / \mathrm{N}$ untuk $\mathrm{R}_{\text {min }}$ dan FWHM. Dalam Rajah 3 dapat dilihat bahawa parameter untuk $\mathrm{R}_{\min }$ optimum berada di tahap 3 dengan panjang gelombang $(785 \mathrm{~nm})$, ketebalan $\mathrm{Cr}(1$ $\mathrm{nm})$, ketebalan Ag (40 nm) dan ketebalan ITO (20 nm). Merujuk kepada Rajah 4 pula, parameter untuk FWHM optimum berada di tahap 3 untuk panjang gelombang (785 $\mathrm{nm})$ dan ketebalan Ag (40 nm), manakala ketebalan $\mathrm{Cr}(0$ $\mathrm{nm})$ dan ITO $(0 \mathrm{~nm})$ di tahap 1 . Garisan mendatar dalam graf mewakili min keseluruhan.

\section{ANALISIS ANOVA}

Seterusnya, analisis ANOVA digunakan untuk menentukan faktor yang memberi kesan signifikan kepada prestasi sensor SPR Cr/Ag/ITO. Keputusan analisis ANOVA ditunjukkan dalam Jadual 5 dan 6. Didapati bahawa antara keempat-empat faktor terpilih, ketebalan Ag memberi kesan tertinggi iaitu sebanyak $44.1 \%$ terhadap nilai $\mathrm{R}_{\text {min }}$, diikuti oleh ketebalan Cr (27\%) dan ketebalan ITO (20\%). Panjang gelombang sinar memberikan pengaruh terkecil, iaitu $8 \%$. Sementara itu, faktor yang paling berkesan untuk nilai optimum FWHM juga adalah ketebalan Ag (76\%). Ini bermakna ketebalan Ag merupakan faktor yang dominan dengan hanya mengubah sedikit ketebalan $\mathrm{Ag}$ memberikan banyak perubahan pada nilai $\mathrm{R}_{\min }$ dan FWHM berbanding faktor lain. Seperti yang diketahui, interaksi antara plasmon permukaan Ag dengan cahaya akan menjana medan elektrik pada permukaan sensor yang menghasilkan isyarat SPR (Manesse et al. 2008; Wenbo \& Cronin 2012). Panjang gelombang, ketebalan ITO memberikan kesan yang kurang iaitu masing-masing sebanyak $12.6 \%$ dan $8.4 \%$, manakala ketebalan $\mathrm{Cr}$ hanya memberikan kesan sebanyak 3\%. Ini bermakna, ketebalan lapisan nano ITO sebanyak 0 - $20 \mathrm{~nm}$ tidak banyak menjejaskan nilai FWHM $(8.4 \%)$, sebaliknya memberi kesan ke atas nilai $\mathrm{R}_{\min }(20 \%)$. Keadaan ini berlaku 


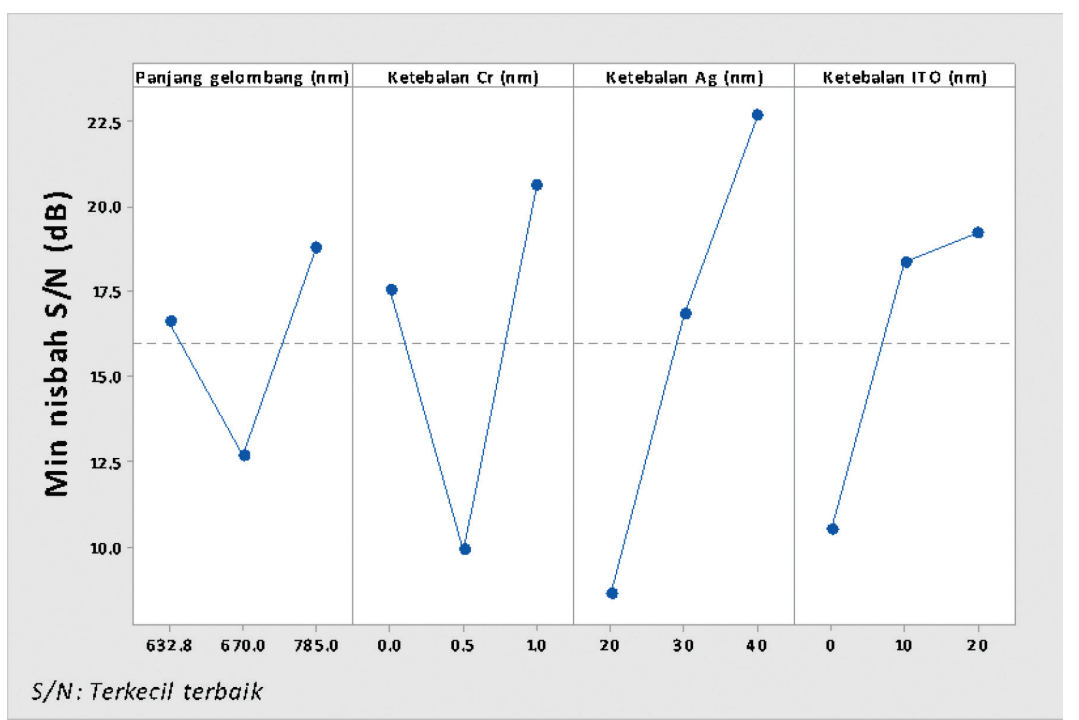

RAJAH 3. Plot kesan faktor bagi $\mathrm{R}_{\min }$

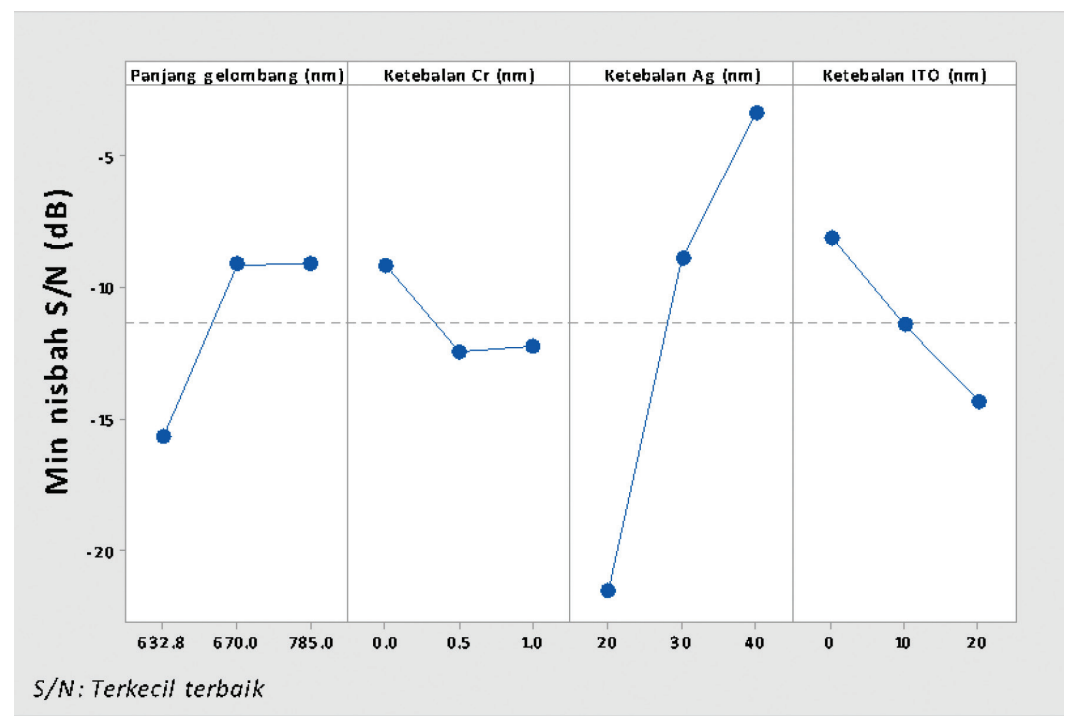

RAJAH 4. Plot kesan faktor bagi FWHM

JADUAL 5. Analisis ANOVA nisbah $\mathrm{S} / \mathrm{N}$ bagi $\mathrm{R}_{\text {min }}$

\begin{tabular}{lcccc}
\hline \multicolumn{1}{c}{ Faktor } & DOF & Adj SS & Adj MS & Kesan faktor (\%) \\
\hline Panjang gelombang $(\mathrm{nm})$ & 2 & 58.20 & 29.10 & 8.5 \\
Ketebalan Cr (nm) & 2 & 184.10 & 92.05 & 27 \\
Ketebalan Ag (nm) & 2 & 300.90 & 150.45 & 44.1 \\
Ketebalan ITO (nm) & 2 & 139.73 & 69.87 & 20.4 \\
Jumlah & 8 & 682.93 & - & - \\
\hline
\end{tabular}

DOF: Darjah kebebasan, Adj SS: Jumlah kuasa dua terlaras, Adj MS: Min kuasa dua terlaras

kerana ciri-ciri optikal ITO menyebabkan pemendapan SPW berlaku (Jamil et al. 2017). Isyarat SPR akan terjejas oleh indeks bias medium yang berhampiran. Merujuk kepada Teory Mie, bahan plasmonik yang dikelilingi oleh medium dengan indeks bias tinggi dijangka mempunyai isyarat SPR yang lebih rendah (Kanehara et al. 2009).

\section{UJIAN PENGESAHAN}

Ujian pengesahan adalah peringkat terakhir dan merupakan langkah penting dalam menentukan ketepatan keputusan berdasarkan pendekatan kaedah Taguchi. Keputusan simulasi dengan kaedah Taguchi ini menjangkakan parameter untuk $\mathrm{R}_{\text {min }}$ optimum adalah: panjang gelombang 
JADUAL 6. Analisis ANOVA nisbah S/N bagi FWHM

\begin{tabular}{lcccc}
\hline Faktor & DOF & Adj SS & Adj MS & Kesan faktor $(\%)$ \\
\hline Panjang gelombang $(\mathrm{nm})$ & 2 & 86.56 & 43.28 & 12.6 \\
Ketebalan Cr $(\mathrm{nm})$ & 2 & 20.31 & 10.16 & 3 \\
Ketebalan Ag $(\mathrm{nm})$ & 2 & 522.14 & 261.07 & 76 \\
Ketebalan ITO $(\mathrm{nm})$ & 2 & 57.83 & 28.92 & 8.4 \\
Total & 8 & 686.84 & - & - \\
\hline
\end{tabular}

DOF: Darjah kebebasan, Adj SS: Jumlah kuasa dua terlaras, Adj MS: Min kuasa dua terlaras

(785 nm), ketebalan Cr (1 nm), ketebalan Ag (40 nm), dan ketebalan ITO (10 nm). Parameter untuk FWHM optimum pula adalah: Panjang gelombang $(785 \mathrm{~nm})$, ketebalan Cr (0 nm), ketebalan Ag (40 nm), dan ketebalan ITO (0 nm). Sehubungan itu, panjang gelombang $(785 \mathrm{~nm})$ yang dioptimumkan berada dalam julat gelombang NIR yang membolehkan sensor tersebut beroperasi dalam gelombang tersebut. Nilai anggaran $\mathrm{R}_{\min }$ dan FWHM optimum daripada gabungan parameter tersebut dalam selang keyakinan 95\% masing-masing adalah 0.0298 dan $0.7966^{\circ}$. Kajian pengesahan dilakukan secara simulasi dengan menggunakan parameter optimum untuk menentukan ketepatan kaedah Taguchi. Perbandingan antara nilai anggaran dan nilai simulasi untuk $\mathrm{R}_{\min }$ dan FWHM menunjukkan nilai simulasi $\mathrm{R}_{\min }$ adalah 0.0053 manakala nilai simulasi FWHM pula adalah $0.7500^{\circ}$. Dapat dilihat nilai simulasi yang diperolehi dan nilai anggaran adalah hampir sama. Ini menunjukkan bahawa kaedah Taguchi berjaya meramal parameter optimum untuk membangunkan sensor SPR $\mathrm{Cr} / \mathrm{Ag} / \mathrm{ITO}$.

\section{KESIMPULAN}

Kesimpulannya, parameter optimum dalam mencapai sensor SPR Cr/Ag/ITO dengan nilai $\mathrm{R}_{\text {min }}$ dan FWHM yang kecil telah berjaya diramal menggunakan kaedah pengoptimunan Taguchi. Lapisan Ag dikenal pasti sebagai faktor kawalan yang mempunyai kesan kuat ke atas isyarat SPR sensor. Selain itu, penambahan lapisan ITO pada pemukaan sensor sebanyak $20 \mathrm{~nm}$ menjejaskan isyarat sensor akibat pemendapan. Malahan tanpa adanya lapisan ITO sensor ini mampu beroperasi dalam NIR. Oleh itu, kaedah Taguchi dapat diperluaskan dalam penyelidikan SPR untuk pengoptimunan parameter sensor kerana ia dapat menjimatkan masa dan sumber.

\section{PENGHARGAAN}

Kerja-kerja ini telah disokong oleh Kementerian Pelajaran Malaysia dengan menggunakan Geran AKU-95 Pusat Kecemerlangan Institusi Tinggi (HiCOE) bersama geran daripada Universiti Kebangsaan Malaysia iaitu DIP-2016022 dan GUP-2016-062. Penulis ingin mengucapkan terima kasih kepada Institut Kejuruteraan Mikro dan Nanoelektronik (IMEN), Universiti Kebangsaan Malaysia atas sokongan yang diberikan.

\section{RUJUKAN}

Chen, H.J., Chang, S.N. \& Tang, C.W. 2017. Application of the Taguchi method for optimizing the process parameters of producing lightweight aggregates by incorporating tile grinding sludge with reservoir sediments. Materials 10(11). doi: $10.3390 /$ ma10111294.

Huang, T. 2017. highly sensitive spr sensor based on d-shaped photonic crystal fiber coated with indium tin oxide at nearinfrared wavelength. Plasmonics 12(3): 583-588.

Jamil, N.A., Menon, P.S., Said, F.A., Tarumaraja, K.A., Mei, G.S. \& Majlis, B.Y. 2017. Graphene-based surface plasmon resonance urea biosensor using Kretschmann configuration. Proceedings of the 2017 IEEE Regional Symposium on Micro and Nanoelectronics, RSM 2017. pp. 112-115. doi:10.1109/ RSM.2017.8069122.

Kanehara, M., Koike, H., Yoshinaga, T. \& Teranishi, T. 2009. Indium tin oxide nanoparticles with compositionally tunable surface plasmon resonance frequencies in the near-IR region. Journal of the American Chemical Society 131(49): 1773617737.

Manesse, M., Sanjines, R., Stambouli, V., Boukherroub, R. \& Szunerits, S. 2008. Preparation and characterization of antimony-doped $\mathrm{SnO} 2$ thin films on gold and silver substrates for electrochemical and surface plasmon resonance studies. Electrochemistry Communications 10(7): 1041-1043.

Menon, P.S., Tasirin, S.K., Ahmad, I. \& Abdullah, S.F. 2014. Taguchi optimization of a SiGe/Si quantum dot SOI-based lateral PIN photodiode. Advanced Materials Research 925: 646-650.

Mukhtar, W.M., Susthitha Menon, P., Shaari, S., Malek, M.Z.A. \& Abdullah, A.M. 2013. Angle shifting in surface plasmon resonance: Experimental and theoretical verification. Journal of Physics: Conference Series 431(1). doi:10.1088/17426596/431/1/012028.

Nengsih, S., Ali Kumar, A., Mat Salleh, M. \& Yahaya, M. 2011. Detection of volatile organic compound gas using localized surface plasmon resonance of gold nanoparticles. Sains Malaysiana 40(3): 231-235.

Oktiawati, U.Y., Mohamed, N.M. \& Burhanudin, Z.A. 2017. Applications of Taguchi method for optimization of dye solar cell design. Sains Malaysiana 46(3): 503-508.

Said, F.A., Menon, P.S., Kalaivani, T., Mohamed, M.A., Abedini, A., Shaari, S., Majlis, B.Y. \& Retnasamy, V. 2015. FDTD analysis of structured metallic nanohole films for LSPR-based biosensor. RSM 2015 - 2015 IEEE Regional Symposium on Micro and Nano Electronics, Proceedings. doi:10.1109/ RSM.2015.7355024.

Salehuddin, F., Mohd Zain, A.S., Idris, N.M., Yamin, A.K.M., Hamid, A.M.A., Ahmad, I. \& Menon, P.S. 2014. Analysis of threshold voltage variance in $45 \mathrm{~nm} \mathrm{n}$-channel device using 
127 orthogonal array method. Advanced Materials Research 903: 297-302.

Simha, S. 2012. Experimental investigation on seismic resistance recycled concrete in filled steel columns - Taguchi's approach. 15th World Conference on Earthquake Engineering (15WCEE) Volume 1.

Sinnathambi, C.M. \& Ismail, R.A.M. 2012. Optimization of n-hexane reforming using taguchi orthogonal array design. Sains Malaysiana 41(7): 885-892.

Wang, Y., Dong, J., Luo, Y., Tang, J., Lu, H., Yu, J., Guan, H., Zhang, J. \& Chen, Z. 2017. Indium Tin oxide coated twomode fiber for enhanced SPR sensor in near-infrared region. IEEE Photonics Journal 9(6): 1-9.

Wenbo, H. \& Cronin, S.B. 2012. A review of surface plasmon resonance-enhanced photocatalysis. Advance Functional Material. https://doi.org/10.1002/adfm.201202148.
Institute of Microengineering and Nanoelectronics (IMEN)

Universiti Kebangsaan Malaysia

43600 UKM Bangi, Selangor Darul Ehsan

Malaysia

*Pengarang untuk surat-menyurat; email: susi@ukm.edu.my

Diserahkan: 31 Mac 2018

Diterima: 27 Jun 2018 